\title{
THE INHERITANCE OF AUTOIMMUNE DISEASE IN MICE: A STUDY OF HYBRIDS OF THE STRAINS NZB AND C3H
}

\author{
MARGARET C. HOLMES and F. M. BURNET \\ Walter and Eliza Hall Institute, Melbourne
}

Received 4.ii.64

\section{INTRODUCTION}

As soon as our stock of NZB mice had been established (Holmes and Burnet, $1963 a$ ), we initiated a programme of hybridisation in the hope of gaining information about the nature of the genetic difference responsible for autoimmune manifestations. The first cross established was with our $\mathrm{C}_{3} \mathrm{H}$ strain. The offspring were large brown mice, much more vigorous, long-lived and healthy than NZB. Relatively few developed a positive Coombs test and at a much later age than was the case with NZB. Kidney lesions of the severe type characteristic of NZB were never seen, but thymus lesions occurred in a large proportion.

These $F_{1}$ mice were studied extensively from serological and histological angles as were another relatively large group of mice obtained by backcrossing $F_{1}$ with NZB. The findings from these studies, plus relevant information in regard to our $\mathrm{C}_{3} \mathrm{H}$ strain, comprise the main part of this paper. One of our chief incentives to have a substantial supply of $F_{1}$ mice was to study the influence of splenic and thymus grafts from the compatible NZB strain, on the appearance of autoimmune manifestations in a relatively insusceptible strain. The results of such experiments will be reported elsewhere. From the original point of view they were wholly negative but there was an interesting correlation of findings in host and grafted thymuses.

\section{MATERIALS AND METHODS}

Mouse strains. The management of the NZB pure line stock has been described previously (Holmes and Burnet, $\mathrm{I}_{96}{ }_{3} a$ ). Inbred $\mathrm{C}_{3} \mathrm{H}$ mice were from the general stock maintained in the laboratory. The $\mathrm{NZB} \times \mathrm{C}_{3} \mathrm{H} \mathrm{F} \mathrm{F}_{1}$ hybrids used in this work were bred from NZB females and $\mathrm{C}_{3} \mathrm{H}$ males as we have found this cross to be consistently more prolific than the $\mathrm{C}_{3} \mathrm{H}$ female by NZB male cross. Both NZB females $\times F_{1}$ males, and $F_{1}$ females $\times$ NZB males, were used to produce the backcross (BC) mice.

Serological methods. The methods used for Direct Coombs (D.C.) tests and papain cell agglutinin (P.C.A.) tirtations have been described elsewhere (Long, Holmes and Burnet, I 963). The antinuclear factor tests were carried out by $\mathrm{Dr} \mathrm{L}$. Norins using standard fluorescent antibody " indirect sandwich" technique.

Histological methods. Standard histological methods were used.

Operative procedures. Many $F_{1}$ mice were used in concomitant studies on the effect of splenectomy, thymectomy and subcutaneous grafting of spleen and thymus and we have occasionally referred to these experiments in the present paper. Standard methods were used which will be described in a later paper. 
Notes on breeding. Considerable difficulty was experienced in building up the pure line NZB stock. Virtually all females became pregnant when mated but many of the litters were lost at birth or soon afterwards. In a survey of the breeding experience of ${ }_{137}$ NZB females, 98.6 per cent. were fertile but only 79.6 per cent. succeeded in rearing a family to weaning and 14.6 per cent. in rearing three litters during their life-time, although almost all were mated five to six times. In general, if any of the litter survived, nearly all did. Considering only the 39.8 per cent. of litters, some of whose members survived to weaning, the average litter size at birth was $5 \cdot 96$, at weaning, $4 \cdot 23$. Overall, the average number of surviving young from a breeding female over her lifetime was $6 \cdot 15$.

TABLE I

Comparison of inbred and hybrid breeding records of $\mathcal{N} Z B$ females

\begin{tabular}{|c|c|c|c|}
\hline \multirow{2}{*}{ Mating } & \multirow{2}{*}{$\begin{array}{l}\text { Number of } \\
\text { litters }\end{array}$} & \multicolumn{2}{|c|}{ Mean family size } \\
\hline & & Born & Weaned \\
\hline $\begin{array}{l}\mathrm{NZB}+\times \mathrm{NZB}^{*} \\
\mathrm{NZB}+\times \mathrm{C}_{3} \mathrm{H}_{\sigma^{*}} \\
\mathrm{NZB}+\times \mathrm{F}_{1} \mathrm{O}^{\circ}\end{array}$ & $\begin{array}{r}501 \\
25 \\
26\end{array}$ & $\begin{array}{l}4 \cdot 7 \\
8 \cdot 5 \\
7 \cdot 6\end{array}$ & $\begin{array}{l}1 \cdot 7^{*} \\
7 \cdot 8 \\
7 \cdot 3\end{array}$ \\
\hline
\end{tabular}

* Only $39 \cdot 8$ per cent. of litters survived. The mean size of surviving litters at weaning was $4 \cdot 2$.

The failure to raise more than 60 per cent. of the litters born was primarily due to some deficiency in the offspring. If the same mothers were mated to $\mathrm{C}_{3} \mathrm{H}$ or $\mathrm{F}_{1}$ $\left(\mathrm{C}_{3} \mathrm{H} \times \mathrm{NZB}\right)$ males, large families were raised with regularity (table $\left.\mathrm{I}\right)$. The small number of litters shown for the hybrids is due mainly to the fact that most of the litters were used experimentally at a very early age. The much higher viability was, however, obvious throughout our experience.

\section{RESULTS}

(i) Colour

The $F_{1}$ mice were uniformly dark brown in colour and the backcross showed approximately equal numbers of black and brown mice. When these were divided according to sex, however, there was an

TABLE 2

Colour and sex distribution of back cross offspring

\begin{tabular}{|c|c|c|c|}
\hline & & $\mathbf{N Z} q \times \mathbf{F}_{1} 0^{\star}$ & $\mathrm{NZ}_{\hat{\sigma}} \times \mathrm{F}_{1}$ 우 \\
\hline $\begin{array}{l}\text { Brown } \\
\text { Black }\end{array}$ & : & 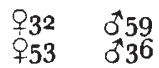 & $\begin{array}{ll}O_{16} 6 & 0^{\pi} 13 \\
\phi_{11} & 0^{\pi} 16\end{array}$ \\
\hline
\end{tabular}

apparent excess of brown males and black females in the main series in which NZB females were mated with $F_{1}$ males. The numbers were not significantly different from the equal numbers to be expected, when the 
cross was in the opposite direction (table 2). No evidence of any association of coat colour with autoimmune manifestations was obtained.

\section{(ii) Life span and causes of death}

$\mathrm{F}_{1}\left(\mathrm{NZB} \times \mathrm{C}_{3} \mathrm{H}\right)$. Relatively small numbers of mice (18 M. 19 F.) were retained for survival until natural death. The only manipulations to which these were subject, were monthly bleedings for Coombs tests. At the time of writing, seven males and three females have survived for more than 800 days. The median age of death for males is 780 days, that for females 664 days. This is much longer than the corresponding ages for NZB, males $45^{\circ}$ days, females 444 . The only important cause of death that was recognised in old $F_{1}$ mice was a generalised tumour of plasmacytoma character in one male and seven female mice. Two other males showed malignant tumours. None showed severe kidney lesions but some degree of membranous glomerulitis was noted.

Splenectomy at three to five weeks of age appeared to have no significant effect on the findings in mice killed at one year and no splenectomised groups were kept beyond this age. By contrast, in splenectomised NZB mice, 2/25 males and 13/20 females died with gross kidney lesions between 250 and 400 days of age (Holmes and Burnet, $1963 b)$.

\section{(iii) Backcross NZB $\times F_{1}(C 3 H \times N Z B)$}

Most of these mice were killed for histological study at one year of age. Of 25 male mice kept until moribund, the median age at death was 536 days, of 28 females 447 days, with two still surviving beyond 760 days. Eight showed severe autoimmune kidney disease ( 3 male, 5 females), while several old mice of both sexes had glomerulonephritis of lesser intensity. Lymphoid tumours recorded as plasmacytomas (6), or reticulum cell tumours (4), were seen in seven males and three females.

\section{(iv) Serological changes: the direct Coombs test}

The times at which the direct Coombs reaction became positive in NZB have been discussed in a previous paper and the results obtained then are included in figure 1. It may be stressed (Holmes and Burnet, 1963a) that with extremely rare exceptions, all mice develop a positive D.C. test by ten months of age and that males are regularly a few weeks ahead of females. On the same figure, we show the strikingly different time sequence shown with $F_{1}$ and B.C.

Very few of the $F_{1}$ mice became positive during the first year of life. Of 120 mice killed around 365 days of age, only four were positive and, of these, three were from a single litter and are discussed later in relation to the spleen findings. During the second year, there was a steady increase in the number of females becoming D.C.+ (fig. I), but very few males converted. The data for the curve over this period are drawn from a diminishing population of mice which, at 15 months, 
comprised 22 males and 24 females, and at 25 months, I I males and 3 females. The terminal downward bend is due to the fact that five mice, after showing positive D.C. tests at some period, usually for several months, became negative in old age. It is of interest that three of the five mice concerned were amongst those dying of plasmacytomas.

Males, on the other hand, showed very few conversions; one became positive at II months and five others at between I 8 and 24 months of age.

A feature of the $F_{1}$ 's was the instability of Coombs conversion. In the six males rated as converters, four subsequently became negative and, of these, three subsequently gave a positive test, two others showed significant partial reaction followed by a negative period and then a

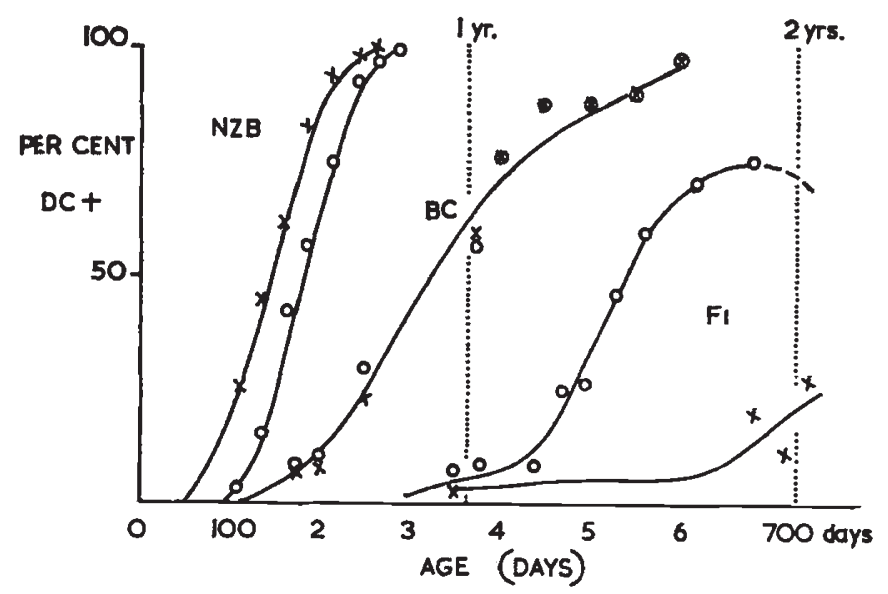

FIG. 1. - To show the percentage of D.C. + mice according to age for $N Z B, F_{1}\left(N Z B \times C_{3} H\right)$ and the backcross $F_{1} \times N Z B$.

period with definitely positive tests. Finally, there are two recorded as negative that, at one or two tests, gave partial reactions. The females were less variable; of twelve recorded as positive, seven showed a definite permanent conversion, while five showed subsequent negative reactions.

The curve for the backcross mice in fig. I is based largely on the findings of tests made at the time of sacrificing a relatively large group of mice at one year of age (350-40o days), when 59 per cent., 34/57, of males, and 57 per cent., 20/35, of females were positive. Points on the curve before and after this were obtained from a small number, 22 males and 18 females, followed at monthly intervals through life and from an additional 30-40 of each sex tested somewhat irregularly between five and nine months of age.

The chief interest of the results with B.C. mice as shown in fig. I is in their deviation from the results to be expected from a mixture of equal numbers of NZB and $F_{1}$. At 12 months we should have expected slightly under 50 per cent. positive, the 25 per cent. level being reached 
at five to six months. Instead, there is a distinct delay in reaching the equivalent 50 per cent. (i.e. 25 per cent.) level and the rise to about 6 o per cent. by 12 months has quite a different character, particularly in the males. It was notable that the reactions in the B.C. mice showed more inconsistency than was observed in NZB. A positive test one month might be followed by a negative at the next test.

\section{(v) Papain-treated cell agglutination (P.C.A.)}

There were 8 I $F_{1}$ mice for which both D.C. and P.C.A. results were available for either a terminal bleeding when killed or from a late routine test bleed (table 3 ). Seventy-five were negative to both tests, five killed at Io months or less, 53 at I2-I 5 months and I 4 from I 6-23 months of age. Of six mice D.C. + , four had P.C.A. titres, 64, 8, 2, 2, the other two being negative. It may be significant that these negative mice were both more than two years old and one was a male. All the other D.C. + mice in this series were female.

\section{TABLE 3}

Comparison of direct Coombs (D.C.) and papain-treated cell agglutination (P.C.A.) tests in $F_{1}$ and B.C. mice

\begin{tabular}{|c|c|c|c|c|}
\hline \multirow{2}{*}{ Mice } & \multirow{2}{*}{ P.C.A. } & \multicolumn{3}{|c|}{ D.C. } \\
\hline & &,+++++ & + &, \pm- \\
\hline$F_{1}$ & $\begin{array}{r}\geqq 128 \\
2-64 \\
0\end{array}$ & $\begin{array}{l}\mathbf{0} \\
3 \\
\mathbf{I}\end{array}$ & $\begin{array}{l}0 \\
1 \\
2\end{array}$ & $\begin{array}{r}0 \\
0 \\
73\end{array}$ \\
\hline B.C. & $\begin{array}{r}\geqq 128 \\
2-64 \\
0\end{array}$ & $\begin{array}{r}22 \\
17 \\
6\end{array}$ & $\begin{array}{l}\mathbf{I} \\
6 \\
5\end{array}$ & $\begin{array}{r}0 \\
8 \\
44\end{array}$ \\
\hline
\end{tabular}

In the B.C. series, the results of the two tests were generally concordant as shown in Table 3. Of those with a strongly positive test, 39/45 had a measurable P.C.A. titre, and all the high titre P.G.A. sera came from D.C. + mice.

As has been discussed in an earlier paper on the findings in NZB (Long et al., I 963), it was concluded that a single population of antibody molecules of variable avidity was concerned in the D.C., I.C. and P.C.A. reactions. The present results with $F_{1}$ and B.C. sera are consistent with the earlier work in indicating that D.G. and P.C.A. tests are based on a unitary immunological process presumably with in the last analysis a single genetic determinant. The part which may be played by somatic mutation will be raised in the discussion. 


\section{(vi) Antinuclear foctor}

Antinuclear factor (A.N.F.) tests on sera were made for us by Dr L. Norins, who will shortly publish a general account of his results (Norins, I964). We are indebted to him for the following summary and table 4 . $\mathrm{C}_{3} \mathrm{H}$ mice show a very low incidence almost confined to older animals. The results with NZB mice have not been easy to interpret. Large numbers of tests mostly made with serum obtained when mice were killed showed a fairly regular 40 per cent. of positive results at all ages over two months. Analysis of the reproducibility of the test and a study of 12 mice bled and tested monthly makes it probable (I) that there is a small proportion of mice which never give more than equivocal \pm readings and must be taken as negative. It should be noted that, in

TABLE 4

Results of A.N.F. tests in $\mathcal{N} Z B C_{3} H$ and hybrid mice

\begin{tabular}{|c|c|c|c|c|c|}
\hline \multirow{2}{*}{ Strain } & \multirow{2}{*}{ Sex } & \multicolumn{4}{|c|}{ Age } \\
\hline & & \multicolumn{2}{|c|}{$<300$ days } & \multicolumn{2}{|c|}{$>300$ days } \\
\hline $\mathrm{C}_{3} \mathrm{H}$ & $\mathbf{M}$ & $5 / 64$ & $8 \%$ & $2 / 32$ & $6 \%$ \\
\hline NZB & $\mathrm{M}$ & $\begin{array}{r}0 / 44 \\
28 / 86\end{array}$ & $\begin{array}{r}0 \% \\
33 \%\end{array}$ & $\begin{array}{r}0 / 47 \\
28 / 65\end{array}$ & $\begin{array}{r}3 \% \\
42 \%\end{array}$ \\
\hline & $F$ & $23 / 80$ & $29 \%$ & $16 / 4 \mathrm{I}$ & $39 \%$ \\
\hline$F_{1}$ & $\underset{\mathrm{F}}{\mathrm{M}}$ & $1 / 28$ & $4 \%$ & $2 / 21$ & $10 \%$ \\
\hline B.C. & $\mathrm{M}$ & $1 / 21$ & & $\begin{array}{r}15 / 3^{8} \\
\end{array}$ & $39 \%$ \\
\hline & $\mathbf{F}$ & 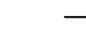 & & $13 / 30$ & $43 \%$ \\
\hline
\end{tabular}

No. positive/no. tested and percentage positive. (Results provided by $\operatorname{Dr}$ L. Norins.)

NZB mice of three months and older, "clean" negatives such as are found with young mice of normal breeds are never seen. (2) Where the titre of a serum is more than three times the end point, positive results are regularly obtained. Tests with dilutions around the end point show variability over three tubes of two-fold dilutions. (3) Many mice have relatively low titres, although a pool of strongly active sera has a titre of $16-32$. (4) In serial bleeds, some mice show changes both up and down in reactivity which are beyond the range of technical variation in the test.

In $F_{1}$ mice less than 300 days of age, there were only two positive results in 49 animals but, in animals killed around one year or later, there was a significantly high incidence of positive results, I I/26 (42 per cent.) in the females only.

Backcross mice tested around one year of age showed about the same 40 per cent. for both sexes as is seen in NZB. The results were examined for any correlation with coat colour or extent of thymic lesions with a completely negative result. Comparison with the D.C. and P.C.A. 
TABLE 5

Absence of correlation between red cell serology and A.N.F. results in B.C.

\begin{tabular}{|c|c|c|c|c|c|c|}
\hline & \multicolumn{3}{|c|}{ Concordant serology } & \multirow{2}{*}{$\begin{array}{c}\text { Not } \\
\text { concordant }\end{array}$} & \multicolumn{2}{|c|}{ Total } \\
\hline & $\begin{array}{l}\text { D.C. }+++,++ \\
\quad \text { P.C.A. } \geqq 128\end{array}$ & $+\underset{8-64}{+,}+$ & $\overline{\mathrm{O}}$ & & $\mathbf{M}$ & $\mathbf{F}$ \\
\hline $\begin{array}{l}\text { A.N.F. }+ \\
\text { A.N.F. }-\end{array}$ & $\begin{array}{l}7 \\
\text { II }\end{array}$ & $\begin{array}{l}3 \\
6\end{array}$ & $\begin{array}{r}8 \\
18\end{array}$ & $\begin{array}{l}8 \\
7\end{array}$ & $\begin{array}{l}\text { I3 } \\
25\end{array}$ & $\begin{array}{l}\text { I3 } \\
17\end{array}$ \\
\hline Totals & & 53 & & I5 & $3^{8}$ & 30 \\
\hline
\end{tabular}

reactions also showed no significant correlation, the figures being shown in table 5. It is clear that whatever the nature of A.N.F. it is not significantly correlated with the manifestations of auto-antibody directed against the red cells.

(vii) Splenic structure

The spleen is intimately concerned with the autoimmune manifestations of NZB (Holmes, Gorrie and Burnet, 1961; Holmes and Burnet, $1963 b)$ and considerable attention has been paid to this organ in the present genetic studies.

There are well marked differences between NZB and $\mathrm{C}_{3} \mathrm{H}$ spleens at six weeks of age. In a comparative study of splenic section from six mice of this age from each of the strains $\mathrm{NZB}, \mathrm{C}_{3} \mathrm{H}$ and $\mathrm{C}_{57} \mathrm{Bl}$, it was found possible to distinguish NZB spleens sharply from the other two types. Differentiation between $\mathrm{C}_{3} \mathrm{H}$ and $\mathrm{C}_{57} \mathrm{Bl}$ was much more difficult.

The important differentiating criteria were the shape of the splenic cross-section, the presence and amount of hæmatopoietic tissue and the distribution of white and red pulp.

I. At six weeks of age the NZB spleen shows a flat triangular section with the two shorter sides distinctly concave. Both $\mathrm{C}_{3} \mathrm{H}$ and $\mathrm{C}_{57} \mathrm{Bl}$ give a rounded cross-section which can be described as a rounded half oval.

2. All NZB mice showed a cellular red pulp containing patches of hæmatopoietic tissue with megakaryocytes. In our experience, megakaryocytes are only seen in mouse lymphoid organs when erythropoiesis is also taking place and their numbers have been taken as an index of the amount of hæmatopoietic tissue. They are in very much smaller numbers in both $\mathrm{C}_{3} \mathrm{H}$ and $\mathrm{C}_{57} \mathrm{Bl}$. The red pulp in five out of six $\mathrm{C}_{3} \mathrm{H}$ mice was distinctly less cellular than that of $\mathrm{C}_{57} \mathrm{Bl}$ and very much less so than NZB.

3. In the NZB mice, the lymphoid tissue nodules tended to be fused and surrounded by a relatively sharply defined zone of paler staining 
cells which separated it from the hæmatopoietic tissue. This was not visible in the other two strains.

As the mice become Coombs positive, NZB spleens enlarge mainly by increase in the amount of hæmatopoietic tissue but often associated with hypertrophy of the lymphoid tissue. Relatively small numbers of NZB spleen weights from mice killed at $35^{\mathrm{I}-400}$ days gave the following median weights - males 6 I $5 \mathrm{mgm}$. (Io), females $670 \mathrm{mgm}$. (12) with a tenfold range (194-1913 males, 237-2776 females) of weights in each sex. Most $\mathrm{C}_{3} \mathrm{H}$ mice showed relatively little enlargement of the spleen and sections made at one year of age differed from those at six weeks, mainly in the relative decrease in amount of red pulp. In a typical $\mathrm{C}_{3} \mathrm{H}$ spleen, the ratio of white to red pulp is one or greater, while in NZB the W/R ratio is always one-quarter or less unless there is hyperplasia or neoplasia of the lymphoid tissue. The median weight of seven $\mathrm{C}_{3} \mathrm{H}$ spleens from female mice killed at one year was $190 \mathrm{mgm}$. with a range of $125^{-}$ $243 \mathrm{mgm}$.

Relatively large numbers of $F_{1}$ mice were killed at about one year of age. Most showed small spleens of $\mathrm{C}_{3} \mathrm{H}$ type, the median weights being male $85 \mathrm{mgm}$., female $105 \mathrm{mgm}$. with the great majority within $30 \mathrm{mgm}$. of the median. As has been mentioned above, there was a relatively high proportion of old female $F_{1}$ 's showing a positive D.C. test. Spleens in mice killed after 450 days of age showed 9/22 (4I per cent.) with NZB type spleens which is considerably higher than the $8 / 5 \mathrm{I}$ ( $\mathrm{I} 6$ per cent.) found in mice killed between 300 and $45^{\circ}$ days of age. There was, however, only a partial correlation of NZB spleen structure with a D.C. + reaction. Of the ir D.C. + mice, five had NZB type spleens, four $\mathrm{C}_{3} \mathrm{H}$ type, while two had lymphomatous changes in the spleen and could not be classified.

The B.C. mice showed the expected wide range of variation in splenic structure but no attempt was made to analyse the differences.

\section{(viii) Appearances in the thymus}

Most mice in both groups were killed around one year of age, primarily to examine the thymus at a time which might be optimal for the recognition of germinal centres and consequent lesions.

The appearances in the thymus of NZB mice have been described in detail (Burnet et al., r 964). The germinal centres and proliferative medullary lesions appear earlier in the females. The lesions are highly variable in intensity and while many thymuses in mice killed after a year or more show large complexes with lesions of various ages, others show only equivocal increases in cellularity of the medulla. These may represent evidence of past germinal centres and, in some earlier tabulations, we used this as justification for using a cumulative assessment of the proportion with thymic lesions. The date given in the paper cited (Burnet et al., r 964 ) provide some evidence that there is in fact a decrease in the proportion of positive findings between 8-9 months and one year. 
The thymuses of old $\mathrm{C}_{3} \mathrm{H}$ mice have been less extensively examined. Twelve animals were killed at 360-370 days of age and thymus sections stained with H.E. and U.P. carefully examined. Compared to thymus sections from young animals, most of these showed a moderate to marked increase in the proportion of medullary tissue and a higher proportion of lymphocytic cells in the medulla. In three mice, there were medullary structures which could be classed as germinal centres in showing both mitoses and pyknotic nuclei. They showed a much less evident surrounding accumulation of lymphocytes than in NZB. These three thymuses, if encountered in NZB, would have been scored as + , two

TABLE 6

Lesions in the thymus of mice killed at 300-400 days of age

\begin{tabular}{|c|c|c|c|c|c|}
\hline \multirow{2}{*}{ Strain } & \multirow{2}{*}{ Sex } & \multicolumn{3}{|c|}{ Grades of thymic lesions } & \multirow{2}{*}{$\begin{array}{l}\text { Number } \\
\text { examined }\end{array}$} \\
\hline & &,+++++ & + & $0^{t}$ & \\
\hline NZB & $\begin{array}{l}\mathbf{M} \\
\mathrm{F}\end{array}$ & 27 & $4 \mathrm{I}$ & & 37 \\
\hline \multirow{2}{*}{$\begin{array}{l}\mathrm{C}_{3} \mathrm{H} \\
\mathrm{F}_{1}\end{array}$} & $\mathbf{F}$ & $\begin{array}{r}40 \\
0\end{array}$ & $\begin{array}{l}33 \\
25\end{array}$ & $\begin{aligned} 21 \\
75\end{aligned}$ & $\begin{array}{l}24 \\
\text { I } 2\end{array}$ \\
\hline & $\mathbf{M}$ & 52 & $3 \mathrm{I}$ & 17 & 29 \\
\hline \multirow{2}{*}{ B.C. } & $\mathbf{M}$ & $\begin{array}{l}04 \\
53\end{array}$ & 16 & $\begin{array}{l}20 \\
16\end{array}$ & 25 \\
\hline & $\mathrm{F}$ & $\begin{array}{l}23 \\
69\end{array}$ & 14 & 17 & 36 \\
\hline
\end{tabular}

Percentages in each grade are shown.

$$
\begin{aligned}
+++ & =\text { Large active complex: all sections involved. } \\
++ & =\text { Germinal centres in } 2 \text { or more sections. } \\
+ & =\text { Definite germinal centre in I section only. } \\
\pm & =\text { Equivocal appearances. } \\
\text { o } & =\text { No abnormality noted. }
\end{aligned}
$$

others which showed local accumulations of lymphocytes in the medulla would have been scored \pm . The seven others were unequivocally negative. We may conclude therefore that, in old $\mathrm{C}_{3} \mathrm{H}$ mice, changes of the same general quality may occur as in the thymus of NZB mice but less frequently, later and at a much lower level of intensity. In discussing the thymic lesions in $F_{1}$ mice, most of which were killed around a year of age, the existence of this activity in $\mathrm{C}_{3} \mathrm{H}$ thymuses must be kept in mind.

The combined results given in table 6 show no significant difference between $F_{1}$ and B.C., both having at 12 months of age a higher incidence of gross lesions and slightly fewer negative results than NZB. The possibility has already been mentioned that this might actually be only an indication that lesions occurred earlier in NZB and that in a proportion of these thymuses from mice killed at one year, evidence of the past occurrence of lesions is not recognised. The only qualitative difference recognised but not critically assessed was the existence in 
some $F_{1}$ thymuses of low grade diffuse germinal centres resembling the two seen in $\mathrm{C}_{3} \mathrm{H}$ mice. Many $\mathrm{F}_{1}$, however, had striking and unequivocal ++ and +++ lesions as active as any to be seen in NZB mice of any age.

\section{DISCUSSION}

The present work represents the first study of the genetics of autoimmune disease in an experimental animal and, in the absence of precedents, it has not been easy to interpret the significance of the observations that we have reported.

It is generally accepted on what is still rather limited and unsystematic evidence that there is an important genetic component in human liability to autoimmune disease, notably rheumatoid arthritis (Blumberg, I96o; Brunjes et al., I96r). In addition, it is known that serological changes characteristic of autoimmune disease such as high gamma globulin content and the presence of rheumatoid factor are more commonly found in symptomless relatives of patients with autoimmune disease than in a control population (Leonhardt, I957; Holman and Deicher, 1960). The age of onset of rheumatoid arthritis and the severity of lesions and symptoms vary widely and it is clear that the phenotypic expression of any overall genetic control is highly subject to modification by, in all probability, both intrinsic and environmental factors.

Burch ( 1963 ) has recently tried to bring order into the age and sex incidence of rheumatoid arthritis and other autoimmune disease (Burch and Rowell, I963) by postulating that the emergence of symptoms requires both the pre-existence in the cells responsible, of specific genetic factors and the occurrence (in the same lines of potentially pathogenic cells) of one or more somatic mutations. Since it is clear that somatic mutation in the developed organism can have no recognisable effect unless the mutant cells can proliferate selectively, an additional hypothesis to account for this is necessary. Burch has used, for this purpose, Burnet's (I 959) "forbidden clone" hypothesis of autoimmune disease and our interest in the NZB strain of mice and its hybrids arose to a large extent from the possibility that the observations on such material might be relevant to these concepts.

In its current form, the forbidden clone hypothesis can be summarised as follows:

I. The recent evidence that there are differences of primary peptide structure between antibodies of different specificity but of the same origin and physical type (Edelmann and Benacerraf, I962; Koshland and Engleberger, I 963) makes it likely that the structure of antibody or of any cell receptors with similar specificity is genetically determined. This provides some experimental justification for the clonal selection approach (Burnet, I959) according to which the patterns of immunological reactivity of an immunologically competent cell are determined by a random process taking place during 
differentiation, either in the course of early development or during redifferentiation of a dedifferentiated cell in later life.

2. The immunological patterns so distributed will include some which correspond to accessible antigenic determinants carried by body components. Cells carrying such "self" reactivity must be removed or inactivated immunologically before release from the region of differentiation. It is reasonable to assume that the essential feature of

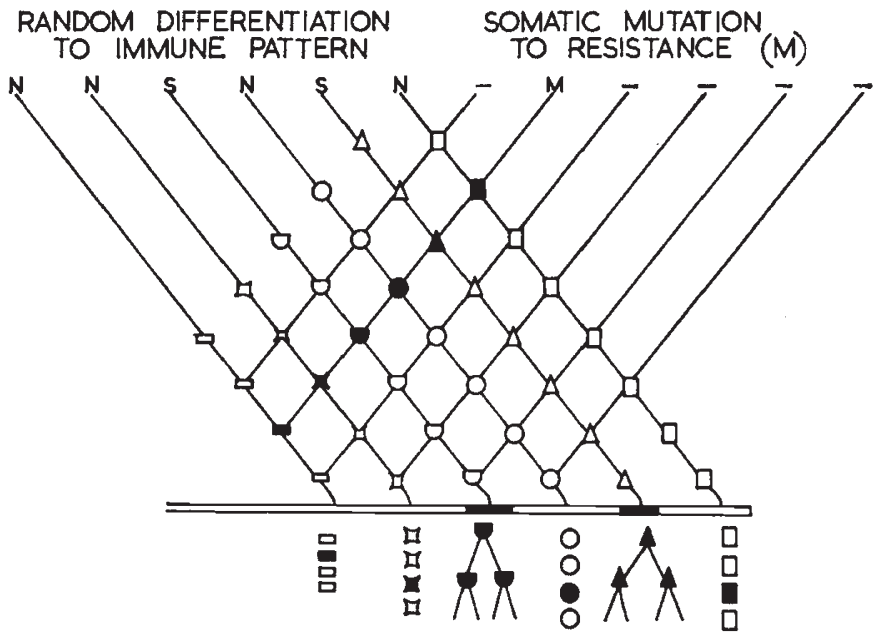

FIG. 2.-A diagram to represent the "forbidden clone" hypothesis of autoimmune disease.

Lymphoid stem cells are assumed to be subject to two types of inheritable modification or mutation. On the left hand side, cells acquire, by some randomly acting mechanism, capacity to react with antigenic determinants, some of which are selfcomponents present in the body $(\mathbf{S})$ while others $(\mathbf{N})$ are not. As cells pass to the general circulation, they are subjected to homeostatic control, indicated by the double line $\mathrm{H}$, such that $\mathrm{S}$ reactive cells are eliminated (dark area of the double line) and do not reach the circulation.

On the right hand side, in individuals subject to autoimmune disease, the somatic mutation $M$ renders any $S$-reactive cell insusceptible to control, so that it can emerge into circulation. This is shown by a black instead of a white symbol for the immunological pattern. The change has no significance if it involves an N-reactive cell line.

"Forbidden" clones are derived from cells (a) whose immunological pattern is directed toward self-components and (b) which have undergone mutation that provokes resistance to the homeostatic process which would normally eliminate them.

the control is damage by a relatively high concentration of antigen on a recently differentiated cell in an appropriate (? thymic) environment.

3. If an appropriate somatic mutation renders cells of the line involved insusceptible to control by antigen excess, then any cells of that line which (randomly) take on a self-reactive pattern will be liable to stimulation by the self antigen in question, giving rise to a proliferating clone of potential pathogenicity. Damage may be mediated either by cells directly or by antibody that they produce.

This concept is illustrated in fig. 2 which is designed to emphasise the independence of the two types of heritable change to which lymphoid stem cells are assumed to be subject, (a) random differentiation of immunological pattern, (b) somatic mutation to resistance 
against the normal control by antigen excess. This general concept could, of course, be elaborated in many directions but the above statement seems to be adequate for the present purpose.

In the NZB mice and their hybrids, we have four manifestations in which the mice differ sharply from normal strains. These are:

(i) A Coombs positive hæmolytic anæmia with a variety of hæmatological, serological and pathological manifestations.

(ii) Germinal centres in the thymic medulla and a variety of secondary changes in that organ.

(iii) Undue frequency of severe (often lethal) membranous glomerulonephritis.

(iv) Positive serological tests for antinuclear factor and in a small proportion positive L.E. cell tests.

The last of these characteristic differences should be qualified by the statement that positive ANF results can be obtained in other breeds of mice. The low incidence in $\mathrm{C}_{3} \mathrm{H}$ has already been described as well as the weak thymic lesions present in old $\mathrm{C}_{3} \mathrm{H}$ mice. It is probable in fact that autoimmune processes will be encountered in a proportion of old mice in many strains when extensive enough search is made. The abnormality of the NZB strain may eventually be found to represent in part a quantitative rather than a wholly qualitative difference from well-known strains. With this qualification, we may consider the influence of genetic factors on each of the four "autoimmune" manifestations.

I. The relatively early onset of a typical autoimmune hæmolytic anæmia involving roo per cent. of NZB mice is the most striking feature of the strain. Work within the NZB type indicated that all the features of the disease showed relatively close correlations. Long $e t$ al. (rg63) concluded that only one broad type of antibody was adequate to account for all the serological features. Males showed an earlier onset than females and all the manifestations were on the average more marked in males.

In the $F_{1}$, all manifestations of hæmolytic disease were greatly delayed, females becoming DC+ during the second year of life and males around 2 years of age. The availability of data in some detail from two genetically uniform populations, NZB and $F_{1}$, prompted an attempt to examine the rate of conversion to D.G. + by Burch's methods. In each group by sexes, therefore, the rate of conversion to D.C. + at 2-weekly intervals was determined in relation to the population still unconverted at the beginning of each interval. For the $F_{1}$, longer primary intervals had to be used but, after smoothing the results quite drastically by using moving 4 -month totals, these were reduced to equivalent 2-weekly rates. When the results for male and female NZB's and female $F_{1}$ 's were plotted on double logarithmic paper, three parallel straight-lines gave a reasonable fit to the points. Only six male $\mathrm{F}_{1}$ 's converted but five of these were in the period from 80-104 weeks and 
the 2-weekly rates of conversion similarly smoothed gave points not far from a fourth parallel line as shown in fig. 3 .

If the lines are in fact parallel, this would indicate that a rate of I per cent. conversion per fortnight is reached at $10 \cdot 4$ weeks for male and 13 weeks for female NZB, while $F_{1}$ mice reach the same level at 46 weeks for females, 70 weeks for males. A 5 per cent. conversion rate per fortnight is reached as follows: NZB M. I5.2 weeks, F. 19.2 weeks.

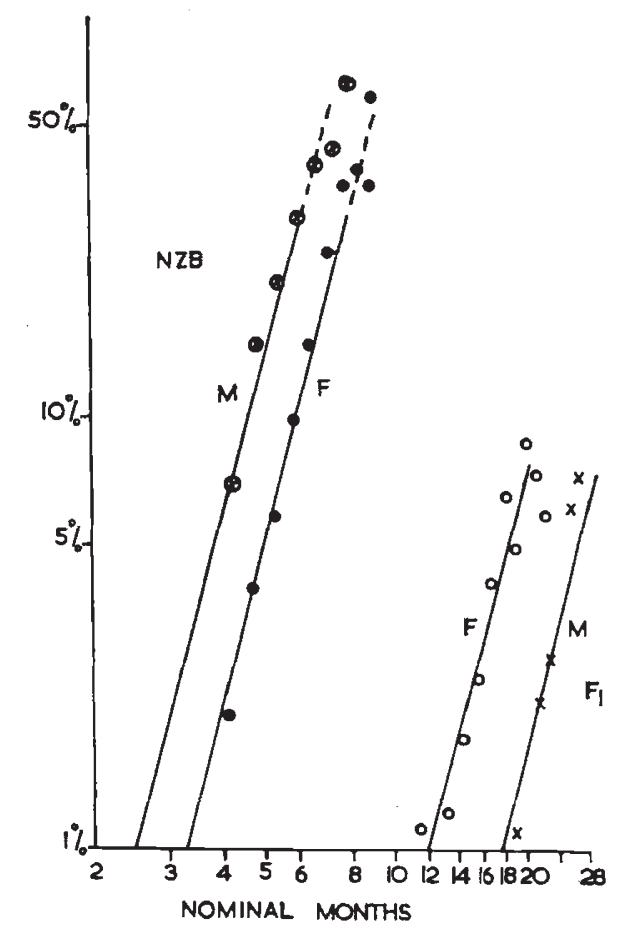

Frc. 3.-A diagram to show the rate of Coombs conversion by sex and age plotted against age, both scales being logarithmic. The points are obtained from the same data used for fig. $I$ and represent the percentage of mice still alive and Coombs negative at the beginning of each 2 -weekly period which have become positive at the end of it. The lines have been drawn parallel to that giving best fit for the female NZB results.

$\mathrm{F}_{1},\left(\mathrm{NZB} \times \mathrm{C}_{3} \mathrm{H}\right)$ hybrids; $\mathrm{M}$ male, $\mathbf{F}$ female.

Nominal months for 4 -weekly periods used for Coombs testing.

$\mathrm{F}_{1}\left(\mathrm{C}_{3} \mathrm{H} / \mathrm{NZB}\right) \mathrm{M}$. Ioo weeks, F. 69 weeks. The slope of the lines is very close to $\mathrm{I}: 4$. We are not competent to interpret these results mathematically but the numerical data have been fully tabulated and can be made available to anyone interested. The least that can be said is that we seem to have a regularity of the same general type which is evident in Burch's studies.

It seems likely that all the manifestations of hæmolytic anæmia are associated with a single process, presumably mediated by an anomalous clone or clones of lymphoid cells and the antibodies they produce. The close association of D.C. + with P.C.A. positive titres in both $F_{1}$ and B.C. shows that both are manifestations of the same broad 
population of antibody molecules with only the minor differences of avidity and specificity that are inherent in any immuno-globulin population.

The splenic appearances are presumably related, in part at least, to the hæmolytic process. In $\mathrm{C}_{3} \mathrm{H}$, the spleens are small and show little hæmatopoietic tissue, while, in almost all NZB mice, there is a high content even in young mice that have not yet become Coombs positive. In the $F_{1}$ mice, the proportion of NZB type spleens increased with age and, if we eliminate three exceptional mice $F_{1}$ 106, I07, I08, from a single litter, 54 mice with $\mathrm{C}_{3} \mathrm{H}$ type spleens over 300 days of age included none with D.C. + , while I 7 with NZB type included 5 D.C. + . Equal attention must, however, be paid to the facts that 12 mice showed large amounts of hæmatopoietic tissue in the spleen without a positive Coombs test, while the three earliest converters $\left(F_{1}\right.$ I06, 107, I08) all had typical $\mathrm{C}_{3} \mathrm{H}$ type spleens.

2. The thymic lesions were approximately equally evident in NZB and the two hybrid populations. In each there was a higher incidence of extensive lesions in the females. It is probable that lesions appeared later in $F_{1}$ than in NZB but the evidence for this is mainly indirect. Our overall impression was that in each group there was a wide range in the number and intensity of lesions and that, at the lower end of the range, lesions present at one stage could subsequently fade into a minor increased cellularity of the medulla. When lesions are few, there is also a real likelihood that a thymus which would be shown to contain one or more germinal centres if examined completely, could be recorded as negative on the single section of each lobe examined as routine.

There is no question that thymic lesions in the three groups are much more frequent and extensive than in the other strains we have available. Nevertheless, the positive findings in old $\mathrm{C}_{3} \mathrm{H}$ females make it difficult to interpret the data genetically.

3. Lethal glomerulonephritis was particularly characteristic of female and splenectomised mice of strain NZB. No examples were seen in $F_{1}$ while in the B.C. there were eight of lethal degree with the usual preponderance of females and several milder examples. Of six examples in B.C. mice, the D.C. conversion times for five were at $4,4,5,8$ and I2 months, i.e. three were unusually early for B.C. while the sixth failed to convert before death at I4 months. There is clearly a suggestion that the two manifestations are either independent or subject to different modifying genes.

4. The A.N.F. results will be discussed elsewhere by Norins ( 1964 ). They appear to be subject to a variety of influences in NZB mice and positive tests have been obtained in mice of several unrelated strains. Within the NZB group, there is no clear relationship with the D.G. and P.C.A. tests, apart from the fact that all are negative in very young mice. In the B.C. mice, there was no correlation between the results of A.N.F. and D.C. + tests. The only interesting correlation is the indication that 
in the $F_{1}$ group, positive A.N.F. tests mostly develop after 300 days of age and involve predominantly female mice. Serial tests on the same animals have, however, not been carried out and most of the females found positive for A.N.F. had a negative Coombs test. It is problematical, therefore, whether this has more than an indirect relationship with the D.C. findings in $\mathrm{F}_{1}$ mice.

It is difficult to provide any satisfactory summary of the genetic situation. At the operational level, all that we can observe is the presence of lesions of autoimmune quality or of auto-antibody in the blood or attached to cells. From this, we can reasonably deduce the presence of pathogenic and/or auto-antibody producing clones of cells within the body, and almost certainly that more than one such clone is present.

The results can easily be fitted into the pattern of the forbidden clone hypothesis but, unless our numerical data on Coombs conversion can supply more information, we have made little progress in relating this to genetic aspects. Perhaps the most that can be said at a fairly superficial level is to postulate a basic genetic anomaly in NZB mice, a process or gene which increases the mutability in somatic lymphoid cells of portions of the genome concerned with susceptibility to immunological homeostasis. The differences and absence of coordination between different autoimmune manifestations could then beinterpreted in terms of figure 2 by differences within a more or less random system in the frequency with which different self patterns arise, by the effective concentration of the self antigens concerned and by the various nongenetic factors such as sex or concomitant infection which can influence an extremely complex situation.

\section{SUMMARY}

I. $F_{1}$ hybrids of the strains $\mathrm{NZB}$ and $\mathrm{C}_{3} \mathrm{H}$ and backcrosses of these with NZB have been studied for the age incidence and character of autoimmune manifestations.

2. $F_{1}$ mice develop positive Coombs tests much later than NZB with sharp differences between the sexes. Females begin to become positive about the end of the first year of life and reach 75 per cent. by 22 months; males, with one exception, have only become positive when nearly two years old.

3. Backcross mice are intermediate in character but do not behave as a simple mixture of NZB and $F_{1}$.

4. Both $F_{1}$ and B.C. show a high proportion of lesions in the thymus; there are no significant differences between them, both being possibly more active in this respect than NZB.

5. Positive antinuclear factor tests showed little correlation with other autoimmune manifestations.

6. The results have been discussed in terms of the forbidden clone concept of autoimmune disease. 


\section{REFERENCES}

BLumberg, B. s. 1960. Arthr. and Rheumat., 3, 178.

brunjes, s., zike, K., ANd Julian, R. 1961. Amer. J. Med., 30, 529.

BURCH, P. R. J. I963. Lancet, I, 1253.

BURGH, P. R. J., AND ROWELL, N. R., 1963. Lancet, 2, 507.

BURNeT, F. M. 1959. Clonal Selection Theory of Immunity. Cambridge U.P.

BURnet, F. M., holmes, M. C., AND ABBot, A. ig64. 7. Path. Bact., 88, 229-245.

edelmann, G. m., and benacerraf, B. 1962. Proc. Nat. Acad. Sci. (Wash.), 48, 1035.

holman, H. AND Deicher, H. R. ig6o. Arthr. and Rheumat., 3, 244.

holmes, м. C., AND bURnet, F. м. ig63a. Ann. Int. Med., 59, 265.

holmes, м. с., and burnet, f: м. i $963 b$. Aust. 7. Exp. Biol., $4 I, 449$.

holmes, M. C., GORRIE, J., AND BURNET, F. M. ig6i. Lancet, $2,638$.

koshland, m. e., and engleberger, f. m. 1963. Proc. Nat. Acad. Sci. (Wash.), 50, 6i. LEONHARDT, T. 1957. Lancet, 2, 1200.

long, G., holmes, м. с., AND bURnet, f. m. ig63. Aust. J. Exp. Biol., 4I, 3 I 5 .

NORINS, L. 1964. J. Immunol. (In the press.) 